\title{
Bacteroides intermedius comb. nov. and Descriptions of Bacteroides corporis sp. nov. and Bacteroides levii sp. nov.
}

\author{
JOHN L. JOHNSON* AND LILLIAN V. HOLDEMAN \\ Department of Anaerobic Microbiology, College of Agriculture and Life Sciences, Virginia Polytechnic \\ Institute and State University, Blacksburg, Virginia 24061
}

\begin{abstract}
Deoxyribonucleic acid homology studies of 66 strains formerly classified as Bacteroides melaninogenicus subsp. intermedius showed two distinct groups with negligible intergroup homology. The larger group, with homology to the type strain of $\boldsymbol{B}$. melaninogenicus subsp. intermedius, is designated Bacteroides intermedius, and the description of the taxon is emended. The other deoxyribonucleic acid homology group, which includes strains that differ from $B$. intermedius in not fermenting sucrose or producing indole, is designated Bacteroides corporis sp. nov.; ATCC $33547^{\mathrm{T}}$ (= VPI 9342) is the type strain. Strains of B. intermedius and $B$. corporis do not ferment lactose, as strains of $B$. melaninogenicus, Bacteroides loescheii, and Bacteroides denticola do. Strain ATCC $29147^{\mathrm{T}}$ is designated the type strain of Bacteroides levii sp. nov. This organism is a pigmenting bacteroides whose strains have been isolated from cattle and include the LEV strain (previously called $B$. melaninogenicus or " $B$. melaninogenicus subsp. levii'). Phenotypic characteristics useful in differentiating among nine species that formerly have been included in or identified as $B$. melaninogenicus are listed.
\end{abstract}

Holdeman and Moore $(10,11)$ recognized two subspecies of saccharoclastic pigmenting bacteroides, Bacteroides melaninogenicus subsp. melaninogenicus and Bacteroides melaninogenicus subsp. intermedius. Because of the phenotypic heterogeneity observed among the saccharoclastic strains of $B$. melaninogenicus, we initiated a study of the deoxyribonucleic acid (DNA) homologies of strains of fermentative bacteroides classified as $B$. melaninogenicus.

In 1980 one of us (J.L.J.) reported that there were three distinct homology groups among 19 strains previously identified as $B$. melaninogenicus subsp. melaninogenicus and three homology groups among 56 strains previously identified as $B$. melaninogenicus subsp. intermedius and gave the phenotypic characteristics useful in differentiating among these homology groups (12). The three major homology groups of strains previously identified as $B$. melaninogenicus subsp. melaninogenicus have been designated $B$. melaninogenicus, Bacteroides loescheii sp. nov. (9a), and Bacteroides denticola $(37,40)$.

Studies of 66 strains previously characterized as $B$. melaninogenicus subsp. intermedius $(8$, 11) are described in this paper. The names proposed here for these homology groups have been published previously (L. V. Holdeman, J. L. Johnson, and W. E. C. Moore, J. Dent. Res. 60[Special Issue A]:414, Abstr. 415, 1981).

In 1977 'Bacteroides melaninogenicus subsp. levii" was described, and the LEV strain (17) was designated the type strain (8). However, this taxon was omitted from the Approved Lists of Bacterial Names (39). This pigmented bacteroides is slightly saccharoclastic and proteolytic and produces acetic, butyric, isobutyric, and isovaleric acids. This subspecies is phenotypically unlike other subspecies of $B$. melaninogenicus (8). On the basis of phenotypic characteristics and the guanine-plus-cytosine $(\mathrm{G}+\mathrm{C})$ content of the DNA, reclassification of $B$. melaninogenicus subsp. levii has been suggested (46). The taxonomic status of this subspecies is evaluated.

\section{MATERIALS AND METHODS}

Strains. The sources of the strains used in the DNA homology studies are shown in Tables 1 and 2 . In addition, homology was tested with the DNAs of strain VPI 6822 (parent strain of American Type Culture Collection [ATCC] $29303^{\mathrm{T}}$, type strain of Bacteroides bivius) and strain VPI 8057 (parent strain of ATCC $29426^{\mathrm{T}}$, type strain of Bacteroides disiens), which are similar phenotypically to strains of $B$. melaninogenicus subsp. intermedius.

Methods of characterization. Phenotypic reactions of the strains were studied by using prereduced media and methods described previously (8). The polyacrylamide gel electrophoretic patterns of soluble cellular proteins were determined as described by Moore et al. (32).

DNA studies. The organisms were grown in a medium prepared as described previously (2); this medium contained mineral salts, $1 \%$ pepticase, $0.5 \%$ yeast 
TABLE 1. Strains having DNA homology with $B$. intermedius strains VPI 4197 and VPI 8944

\begin{tabular}{|c|c|c|c|}
\hline \multirow{2}{*}{ VPI no. } & \multicolumn{2}{|c|}{$\begin{array}{l}\text { \% DNA homology with } \\
\text { reference DNA of: }\end{array}$} & \multirow{2}{*}{ Strain derivation and other information ${ }^{a}$} \\
\hline & VPI 4197 & VPI 8944 & \\
\hline \multicolumn{4}{|r|}{ - } \\
\hline VPI 4197 & $100^{b}$ & 36 & $\begin{array}{l}\text { Finegold B422; empyema; parent strain of ATCC } 25611^{\mathrm{T}} \text {, the } \\
\text { type strain of } B \text {. intermedius }(39)^{c}\end{array}$ \\
\hline VPI 13043 & 87 & 55 & Socransky S-98 \\
\hline VPI 9849 & 84 & & Lambe $275-70 \mathrm{~A}$, serogroup $\mathrm{C}$ immunizing strain (15) \\
\hline VPI 13042 & 81 & 46 & Socransky S-97 \\
\hline VPI 13048 & 80 & 45 & Socransky S-108 \\
\hline VPI D10A-24 & 78 & 38 & Tooth surface, severe periodontitis \\
\hline VPI 13044 & 77 & 42 & Socransky S-101 \\
\hline VPI D16B-12A & 77 & 42 & $\begin{array}{l}\text { Gingival sulcus, moderate periodontitis; same person as D16A- } \\
\text { 32; same sample as VPI D16B-28A }\end{array}$ \\
\hline VPI 12510 & 76 & 41 & Williams $3 \mathrm{~b} / \mathrm{L}-75$ \\
\hline VPI 12528 & 76 & 39 & Socransky 581 \\
\hline VPI 13024 & 76 & 47 & Socransky S-14 \\
\hline VPI 13029 & 76 & 50 & Socransky S-22 \\
\hline VPI D11B-5 & 76 & 48 & Gingival sulcus, moderate periodontitis \\
\hline VPI D16A-32 & 76 & 39 & $\begin{array}{l}\text { Tooth surface, moderate periodontitis; same person as VPI } \\
\text { D16B-12A }\end{array}$ \\
\hline VPI D1C-2 & 74 & 46 & Gingival sulcus, moderate periodontitis \\
\hline VPI D10D-1 & 74 & 40 & $\begin{array}{l}\text { Gingival sulcus, severe periodontitis; same person as VPI } \\
\text { D10A-24 }\end{array}$ \\
\hline VPI D10B-7 & 73 & 40 & $\begin{array}{l}\text { Gingival sulcus, severe periodontitis; same person as VPI } \\
\text { D10D-1 }\end{array}$ \\
\hline VPI D10D-18 & 73 & 37 & $\begin{array}{l}\text { Gingival sulcus, severe periodontitis; same site as VPI D10D-1; } \\
\text { same person as VPI D10A-24 }\end{array}$ \\
\hline VPI 6092 & 72 & & Lambe $935 \mathrm{~F}$; abdominal wound \\
\hline VPI 13049 & 72 & & Socransky S-109 \\
\hline VPI D2B-42 & 72 & 40 & Gingival sulcus, moderate periodontitis \\
\hline VPI D13D-11 & 72 & 39 & Gingival sulcus, moderate periodontitis \\
\hline VPI 9123 & 71 & 39 & $\begin{array}{l}\text { Wisconsin Department of Hygiene B-12; VPI 4200; Finegold } \\
\text { B485; maxillary sinus drainage }\end{array}$ \\
\hline VPI 9182 & 71 & 37 & Throat \\
\hline VPI 13028 & 71 & 41 & Socransky S-20 \\
\hline VPI D1C-4 & 71 & 45 & $\begin{array}{l}\text { Gingival sulcus, moderate periodontitis; same sample as VPI } \\
\text { D1C-2 }\end{array}$ \\
\hline VPI D16B-28A & 71 & 38 & $\begin{array}{l}\text { Gingival sulcus, moderate periodontitis; same sample as VPI } \\
\text { D16B-12A }\end{array}$ \\
\hline VPI 13039 & 69 & 41 & Socransky S-90 \\
\hline VPI D19B-24 & 69 & 40 & Gingival sulcus, juvenile periodontitis \\
\hline VPI 12507 & 68 & & Williams B9-74 \\
\hline VPI 12527 & 68 & 48 & Socransky 576 \\
\hline VPI 13032 & 68 & 42 & Socransky S-47 \\
\hline VPI D25D-29 & 68 & 46 & Gingival sulcus, juvenile periodontitis \\
\hline VPI D28M-18 & 68 & 46 & $\begin{array}{l}\text { Gingival sulcus, severe periodontitis; same person as VPI D28C- } \\
1\end{array}$ \\
\hline VPI D30A-17 & 68 & 42 & Gingival sulcus, advanced periodontitis \\
\hline VPI 13038 & 66 & 46 & Socransky S-89 \\
\hline VPI D12B-20 & 66 & 41 & Gingival sulcus, moderate periodontitis \\
\hline VPI 13037 & 65 & 41 & Socransky S-88 \\
\hline VPI 9042 & 63 & 50 & Hill (CDC 1976); Lambe 730-74, serogroup C (16) \\
\hline VPI 12987 & 62 & 32 & Slots $15-7 \mathrm{~K}-2$ \\
\hline VPI D28C-1 & 62 & 33 & Tooth surface, severe periodontitis \\
\hline VPI 13033 & 61 & & Socransky S-51 \\
\hline VPI D33B-8 & 59 & 40 & Gingival crevice, healthy gingiva \\
\hline \multicolumn{4}{|r|}{ a) } \\
\hline VPI 8944 & 34 & $100^{b}$ & $\begin{array}{l}\text { NCTC 9336; Vincent's angina; parent strain of ATCC } 33563 \text {; } \\
\text { Lambe } 729-74 \text {, serogroup C (15) }\end{array}$ \\
\hline VPI 12526 & 42 & 99 & Socransky 377 ; oral \\
\hline VPI 13025 & 39 & 93 & Socransky S-15 \\
\hline VPI 12516 & 41 & 90 & Williams JPI-77 \\
\hline VPI 12515 & 41 & 88 & Williams LH-107; dental \\
\hline
\end{tabular}


TABLE 1-Continued

\begin{tabular}{|c|c|c|c|}
\hline \multirow{2}{*}{ VPI no. } & \multicolumn{2}{|c|}{$\begin{array}{l}\text { \% DNA homology with } \\
\text { reference DNA of: }\end{array}$} & \multirow{2}{*}{ Strain derivation and other information ${ }^{a}$} \\
\hline & VPI 4197 & VPI 8944 & \\
\hline VPI D25B-1 & 37 & 87 & Gingival sulcus, juvenile periodontitis \\
\hline VPI D16B-7 & 38 & 86 & Gingival sulcus, moderate periodontitis \\
\hline VPI 4203 & 37 & 85 & $\begin{array}{l}\text { Finegold B515; laryngotomy; Lambe } 724-74 \text {, serogroup C (16); } \\
\text { parent strain of ATCC } 25261\end{array}$ \\
\hline VPI 8946 & 35 & 84 & NCTC 9338; empyema; Lambe 206-74, serogroup C (15) \\
\hline VPI 11328 & 31 & 83 & Williams B-18; gingiva \\
\hline VPI D27C-15 & 31 & 81 & Tooth surface, severe periodontitis \\
\hline VPI D28D-12 & 29 & 83 & Gingival sulcus, periodontitis \\
\hline VPI 11335 & 34 & 80 & Carlsson G11a-d2; root canal \\
\hline VPI 9854 & 36 & 79 & Lambe $297-74 G$, Lambe serogroup C (16) \\
\hline VPI D22B-23 & 33 & 73 & Gingival sulcus, juvenile periodontitis \\
\hline VPI 9145 & & 62 & Williams T 584/72; plaque; Lambe $731-74$, serogroup C (16) \\
\hline
\end{tabular}

${ }^{a}$ ATCC, American Type Culture Collection, Rockville, Md.; Carlsson, J. Carlsson, University of Umea, Umea, Sweden; CDC, Centers for Disease Control, Atlanta, Ga.; Finegold, S. M. Finegold, Wadsworth Veterans Administration Hospital, Los Angeles, Calif.; Hill, G. Hill, Duke University, Durham, N.C., Lambe, Dwight W. Lambe, Jr., Department of Microbiology, East Tennessee State University, Johnson City; NCTC, National Collection of Type Cultures, Central Public Health Laboratory, London, England; Slots, J. Slots, State University of New York, Buffalo; Socransky, S. S. Socransky, Forsyth Dental Center, Boston, Mass.; Williams, R. A. D. Williams, The London Hospital Medical College, London, England. Unless otherwise designated, strains were isolated at the Anaerobe Laboratory, Virginia Polytechnic Institute and State University. All isolates were from humans. Tooth surface samples were taken coronal to the gingival margin of affected sites after superficial cleaning of the surface with sterile toothpicks. The advanced periodontitis sample was from an individual (ca. 50 years old) with advanced generalized periodontitis. Juvenile periodontitis samples were from individuals 11 to 25 years old with severe destruction essentially limited to permanent first molars and incisors. Moderate periodontitis samples were from individuals 35 to 55 years old with chronic periodontitis generalized to all four quadrants, pocket depths of 5 to $7 \mathrm{~mm}$, and no history of rapid loss of attachment. Severe periodontitis samples were from persons 18 to 30 years old with a loss of attachment of $5 \mathrm{~mm}$ or more on any surface of eight or more teeth not limited to first molars or incisors.

${ }^{b}$ Homology with reference DNA was normalized to $100 \%$.

$c$ The numbers in parentheses are reference numbers.

extract, $1 \%$ dehydrated brain heart infusion broth (Difco Laboratories, Detroit, Mich.), 1\% glucose, $0.03 \%$ cysteine, $0.03 \%$ sodium formaldehyde sulfoxalate, $0.01 \%$ heme, and $0.05 \mathrm{M}$ potassium phosphate

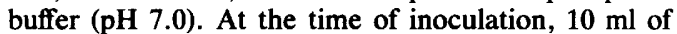
sterile $10 \% \mathrm{NaHCO}_{3}$ was added to each 1 liter of medium. Cultures were grown and DNA was harvested as described previously (9a). High-molecularweight DNA (for nick-translation labeling) was isolated by the method of Marmur (28), and other DNA preparations were isolated by an hydroxyapatite procedure (13). Thermal melting points were used to determine the $\mathrm{G}+\mathrm{C}$ contents of the DNA preparations (13). Labeled DNA was prepared in vitro either by nick translation (13) or by iodination. Fragmented denatured DNA was labeled with ${ }^{125}$ I by using a variation of the thallium chloride method of Tereba and McCarthy (44). DNA homology values were determined by using an $S 1$ nuclease procedure (13). The reassociation vials were incubated for $24 \mathrm{~h}$ at $62^{\circ} \mathrm{C}$. We have described other details of the methods used elsewhere $(9 \mathrm{a})$.

\section{RESULTS AND DISCUSSION}

Of the 66 isolates studied, 42 had relatively high homology with reference DNA from $B$. melaninogenicus subsp. intermedius strain VPI 4197 , and 15 had high homology with reference
DNA from strain VPI 8944 (Table 1). Homologous and heterologous values for individual strains are given in Table 1, and average intragroup homology values are shown in Table 3. Although the reciprocal homology values for the two reference strains were nearly equal ( 34 and $36 \%$ [Table 1]), there was a $6 \%$ difference in the average heterologous values ( 36 and $42 \%$ [Table 3]). In general, lower values were obtained with reference DNA from strain VPI 4197 than with reference DNA from strain VPI 8944. Strains in the VPI 4197 and VPI 8944 homology groups produced different polyacrylamide gel electrophoresis patterns (Fig. 1), but none of the cultural phenotypic traits which we tested clearly differentiated between the two homology groups.

The intergroup homology observed between strains in the VPI 4197 and VPI 8944 homology groups was similar to that previously reported (9a) between $B$. melaninogenicus subgroups (represented by VPI 2381 [ = ATCC $25845^{\mathrm{T}}$ ] and VPI 9343) or between $B$. loescheii subgroups (represented by ATCC $15930^{\mathrm{T}}$ and VPI D1C-20).

We believe that the VPI 4197 and VPI 8944 homology groups are sufficiently distinct to be 
TABLE 2. Strains in the B. corporis VPI 9342 homology group and their sources

\begin{tabular}{|c|c|c|}
\hline VPI no. & $\begin{array}{c}\% \text { DNA } \\
\text { homology with } \\
\text { reference DNA } \\
\text { from VPI } 9342\end{array}$ & Strain derivation and other information ${ }^{a}$ \\
\hline VPI 9342 & $100^{b}$ & $\begin{array}{l}\text { Lambe } 532-70 A \text {; cervical swab; Lambe serogroup C-1 (16); parent strain of } \\
\text { ATCC } 33547^{\mathrm{T}} \text {, the proposed type strain }\end{array}$ \\
\hline VPI 6018 & 94 & Lambe $867-70 \mathrm{D}$; perineal incision \\
\hline VPI 8667 & 88 & $\begin{array}{l}\text { University of Virginia School of Medicine; nasal septum; Lambe 728-24, } \\
\text { serogroup C-1 (16) }\end{array}$ \\
\hline VPI 10443 & 85 & Lambe 1701-74E; wound \\
\hline VPI 8558 & 81 & Lambe $237-73 \mathrm{C}$; rectal abscess \\
\hline VPI 11329 & 76 & Williams 2B (JK2B); urethra \\
\hline VPI 12517 & 64 & Williams $532-70 \mathrm{~A}$ \\
\hline
\end{tabular}

${ }^{a}$ See Table 1 , footnote $a$.

${ }^{b}$ Homology with reference DNA was normalized to $100 \%$.

$c$ The numbers in parentheses are reference numbers.

separate species, but at this time we are not proposing that they be classified as distinct species, principally because we know of no cultural phenotypic characteristic that is useful for differentiating between them.

Strain VPI 4197 is the parent strain of ATCC $25611^{\mathrm{T}}$, the type strain of $B$. melaninogenicus subsp. intermedius. Because the related subgroups (i.e., VPI 4197 and VPI 8944 subgroups) have negligible DNA homology with $B$. melaninogenicus, B. loescheii (9a), or B. denticola (37, 40) or with phenotypically similar species that do not form colonies with dark pigment (Table 4), we propose that this taxon, B. melaninogenicus subsp. intermedius, be elevated to species rank as Bacteroides intermedius comb. nov., with ATCC $25611^{\mathrm{T}}$ as the type strain.

The phenotypic characteristics of $B$. intermedius are given in Tables 5 and 6 and in the species description below. Polyacrylamide gel electrophoresis patterns are shown in Fig. 1.

Because there are several distinct taxa among the strains that previously have been classified as $B$. melaninogenicus subsp. intermedius, previous research concerning the characteristics of this taxon is difficult to interpret unless specific strains were identified and can be related to proposed taxa. The relationships of some strains

TABLE 3. Reciprocal homology values for strains in the $B$. intermedius VPI 4197 and VPI 8944 groups

\begin{tabular}{lcc}
\hline \multirow{2}{*}{$\begin{array}{c}\text { DNA homology } \\
\text { group }\end{array}$} & \multicolumn{2}{c}{$\begin{array}{c}\text { Avg homology (\%) with reference } \\
\text { DNAs from: }\end{array}$} \\
\cline { 2 - 3 } & $\begin{array}{c}\text { VPI } 4197 \text { group } \\
\text { strains }\end{array}$ & $\begin{array}{c}\text { VPI } 8944 \text { group } \\
\text { strains }\end{array}$ \\
\hline VPI 4197 & $72 \pm 6^{b}$ & $42 \pm 5$ \\
VPI 8944 & $36 \pm 4$ & $84 \pm 8$ \\
\hline
\end{tabular}

${ }^{a}$ All values in Table 1 except the homologous values were used for these calculations.

${ }^{b}$ Average \pm standard deviation. to the homology groups described here are shown in Table 7 . Information from many previously published reports has been included in the species descriptions given below.

Bacteroides intermedius: emended description. Bacteroides intermedius (Holdeman and Moore) comb. nov. (in.ter.me' di.us. L. adj. intermedius intermediate; basionym, Bacteroides melaninogenicus subsp. intermedius Holdeman and Moore 1970, 33).

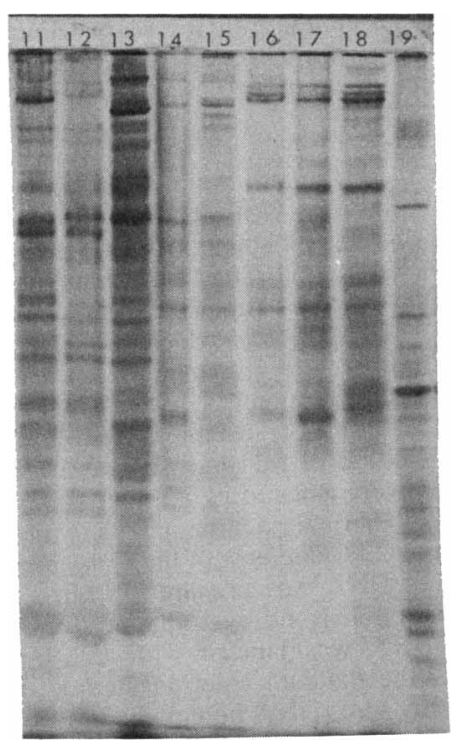

FIG. 1. Polyacrylamide gel electrophoresis patterns of strains of $B$. intermedius and $B$. corporis. Lanes 11 to $13, B$. intermedius VPI 4197 group (lane 11, VPI 4197 [ = ATCC $25611^{\mathrm{T}}$ ]; lane 12, VPI D16A32; lane 13, VPI 9182); lanes 14 and $15, B$. intermedius VPI 8944 group (lane 14, VPI 8944 [= NCTC 9336]; lane 15, VPI 11328); lanes 16 to $18, B$. corporis (lane 16, VPI 9342 [= ATCC $33547^{\mathrm{T}}$ ]; lane 17, VPI 10443; lane 18, VPI 8558); lane 19, Streptococcus faecalis U420 reference culture. 
TABLE 4. DNA homology among some saccharoclastic bacteroides

\begin{tabular}{lccc}
\hline & \multicolumn{3}{c}{$\begin{array}{c}\text { \% Homology with reference } \\
\text { DNA from strains: }\end{array}$} \\
\cline { 2 - 4 } & VPI 4197 & VPI 8944 & VPI 9342 \\
\hline $\begin{array}{l}\text { B. intermedius VPI 4197 } \\
(=\text { ATCC 25611 })^{a}\end{array}$ & $100^{b}$ & 36 & 5 \\
$\begin{array}{l}\text { B. intermedius VPI 8944 } \\
(=\text { ATCC 33563) }\end{array}$ & 34 & $100^{b}$ & 5 \\
$\begin{array}{l}\text { B. corporis VPI 9342 } \\
(=\text { ATCC 33547 }\end{array}$ & 9 & 13 & $100^{b}$ \\
$\begin{array}{l}\text { B. bivius VPI 6822 } \\
(=\text { ATCC 29303 }\end{array}$ & 8 & 22 & 9 \\
$\begin{array}{l}\text { B. disiens VPI 8057 } \\
(=\text { ATCC 29426 }\end{array}$ & 25 & 28 & 20 \\
\hline
\end{tabular}

${ }^{a}$ A superscript $\mathrm{T}$ indicates a type or proposed type strain.

${ }^{b}$ Homology with reference DNA was normalized to $100 \%$.

Most cells are 0.4 to $0.7 \mu \mathrm{m}$ wide by 1.5 to 2 $\mu \mathrm{m}$ long (Fig. 2). Some cells are up to $12 \mu \mathrm{m}$ long.

Surface colonies on rabbit blood agar are circular, entire, low convex, 0.5 to $2 \mathrm{~mm}$ in diameter, translucent, smooth, and beta-hemolytic. Older or larger colonies sometimes are opaque. After anaerobic incubation for $48 \mathrm{~h}$, colonies are tan, gray, reddish brown, or black. Pigmentation of colonies occurs more rapidly on agar containing hemolyzed blood than on agar supplemented with whole blood. On hemolyzed rabbit blood agar, about one-third of the strains produce dark brown to black colonies within 2 days, another third produce such colonies within 7 days, and most of the rest produce such colonies within 14 days. An occasional strain require 18 to 21 days to produce definite pigment. The pigment of the colonies is due principally to protoheme (36).

Glucose broth cultures are turbid with a smooth (sometimes ropy or slightly mucoid) sediment and have a final $\mathrm{pH}$ of 4.9 to 5.4 .

The major fermentation acids detected in cultures of the type strain grown in broth medium containing $1 \%$ peptone, $1 \%$ yeast extract, $1 \%$ glucose, vitamin $\mathrm{K}$, and hemin (8) are as follows (in milliequivalents per $100 \mathrm{ml}$ of culture): succinic, 4 ; acetic, 2 . Isobutyric acid (0.1 to 0.4 $\mathrm{meq} / 100 \mathrm{ml})$ and isovaleric acid $(0.1$ to 0.4 $\mathrm{meq} / 100 \mathrm{ml}$ ) also are detected. No hydrogen is detected in the headspace gas. Similar products are obtained with other strains of this species. Neither lactate nor pyruvate is used; threonine is not converted to propionate.

Hemin is required for growth of most strains. Vitamin K often is highly stimulatory or required for fermentation. Growth is inhibited by $6.5 \% \mathrm{NaCl}$. The type strain grows well at tem- peratures between 25 and $45^{\circ} \mathrm{C}$. In poorly buffered media (e.g., prereduced peptone-yeast extract-sugar media [8]), some strains grow better in an anaerobic atmosphere containing $10 \%$ (rather than 100\%) carbon dioxide, probably due to the higher $\mathrm{pH}$ when the lower concentration of carbon dioxide was used.

Strains produce superoxide dismutase (4) and do not hydrolyze dextran (7).

The type strain and 11 other strains (6 strains from the VPI 4197 homology subgroup and 6 strains from the VPI 8944 homology subgroup) are strongly positive for acid and alkaline phosphatase, phosphoamidase, and alpha-glucosidase. Very weak reactions occur for $\mathrm{C} 4$ esterase and C8 esterase lipase (API ZYM system; Analytab Products, Plainview, N.Y.) (Roger Kelley, unpublished data).

Aspartate, asparagine, cysteine, and serine stimulate growth and are metabolized by strain ATCC 25261 (VPI 8944 subgroup [Table 7]) (31, 48).

Diaminopimelic acid is the only dibasic amino acid in the peptidoglycan. No heptose or 2-keto3-deoxyoctulosonic acid has been detected (5).

Other characteristics of this species are given in Table 5.

This species is a common inhabitant of human gingival crevices and has been isolated from human clinical specimens.

The $\mathrm{G}+\mathrm{C}$ content of the DNA is 41 to 44 mol\% (45-47; this study).

The type strain is ATCC $25611^{\mathrm{T}}$ (= VPI 4197 $=$ Finegold B422).

Seven strains previously classified as $B$. melaninogenicus subsp. intermedius had negligible homology with reference DNA from either VPI 4197 or VPI 8944 . These strains had from 64 to 94\% homology (Table 2) with reference DNA from VPI 9342 (parent strain of ATCC 33547). For these strains we propose the name Bacteroides corporis, with ATCC $33547^{\mathrm{T}}$ as the type strain.

Bacteroides corporis. Bacteroides corporis sp. nov. (cor'po.ris. L. gen.n. corporis of the body; pertaining to the isolation of this organism from human clinical specimens).

Cells in glucose broth cultures are 0.9 to 1.6 by 1.6 to $4 \mu \mathrm{m}$ and occur singly, in pairs, and in short chains (Fig. 3). In many cultures the cells are coccoid. Occasionally, longer cells (up to 11 $\mu \mathrm{m})$ are observed.

Surface colonies on anaerobic blood agar plates are minute to $1 \mathrm{~mm}$ in diameter, circular, entire, convex, and (after 48 to $72 \mathrm{~h}$ ) buff with brown edges. Dark brown colonies developed after 4 to 7 days.

Glucose broth cultures are turbid, often with a smooth or ropy sediment that tend to adhere to the bottom of the tube, and have a final $\mathrm{pH}$ of 4.8 
TABLE 5. Phenotypic characteristics of $B$. intermedius and B. corporis ${ }^{a}$

\begin{tabular}{|c|c|c|c|c|c|c|}
\hline \multirow{2}{*}{ Characteristic } & \multicolumn{4}{|c|}{ B. intermedius } & \multicolumn{2}{|c|}{ B. corporis } \\
\hline & $\begin{array}{l}\text { VPI } 4197 \\
\text { ATCC } 25611\end{array}$ & $\begin{array}{l}38 \text { other } \\
\text { strains }\end{array}$ & $\begin{array}{c}\text { VPI } 8944 \\
\text { ATCC } 33563\end{array}$ & $\begin{array}{l}15 \text { other } \\
\text { strains }\end{array}$ & $\begin{array}{c}\text { VPI } 9343 \\
\text { ATCC } 33574\end{array}$ & $\begin{array}{l}5 \text { other } \\
\text { strains }\end{array}$ \\
\hline \multicolumn{7}{|l|}{ Acid from: } \\
\hline Fructose & $\mathbf{A}$ & $A(74)^{b}$ & $\mathbf{A}$ & A & - & $A(80)$ \\
\hline Glycogen & $\mathbf{A}$ & A & $\mathbf{A}$ & $A(87)$ & A & $\mathbf{A}$ \\
\hline Gum arabic & - & $-(13)$ & - & $-(7)$ & - & - \\
\hline Inulin & $\mathbf{w}$ & $A(78)$ & $\mathbf{A}$ & $v(60)$ & - & - \\
\hline Maltose & A & $A(92)$ & $\mathbf{A}$ & A & $\mathbf{A}$ & $\mathbf{A}$ \\
\hline Mannose & $\mathbf{w}$ & $v(47)$ & - & - & $\mathbf{A}$ & $A(80)$ \\
\hline Raffinose & $\mathbf{A}$ & $v(42)$ & $\mathbf{A}$ & $A(93)$ & - & - \\
\hline Starch & $\mathbf{A}$ & A (89) & $\mathbf{A}$ & $\mathbf{A}$ & $\mathbf{A}$ & $\mathbf{A}$ \\
\hline Sucrose & $\mathbf{A}$ & $A(95)$ & $\mathbf{A}$ & $\mathbf{A}$ & - & - \\
\hline Trehalose & - & $-(3)$ & - & - & - & - \\
\hline Xylan & - & $-(3)$ & - & $-(33)$ & - & - \\
\hline Milk digestion & + & + & + & $+(87)$ & + & $+(80)$ \\
\hline Meat digestion & - & $v(53)$ & - & $v(40)$ & - & $v(40)$ \\
\hline Indole & + & + & + & + & - & - \\
\hline Lipase on egg yolk agar & + & $+(94)$ & - & + & - & - \\
\hline $\mathrm{H}_{2} \mathrm{~S}$ (SIM medium) & - & $-(22)$ & - & - & - & - \\
\hline Starch hydrolysis & + & $+(92)$ & + & + & + & + \\
\hline
\end{tabular}

\footnotetext{
${ }^{a}$ All strains produced acid (at $\mathrm{pH}$ values below 5.5 ) from dextrin and glucose; all strains digested gelatin. No strain produced acid from amygdalin, arabinose, cellobiose, erythritol, esculin, inositol, lactose, larch arabinogalactan, mannitol, melezitose, melibiose, rhamnose, ribose, salicin, sorbitol, or xylose; no strain grew in peptone yeast extract glucose medium containing $20 \%$ bile. No strain reduced nitrate or produced catalase or lecithinase; no strain hydrolyzed esculin. Negligible gas was produced in peptone yeast extract glucose agar deep cultures. A, $\mathrm{pH}$ below 5.5; w, pH 5.5 to 5.7 and at least $0.3 \mathrm{pH}$ unit below the $\mathrm{pH}$ of a peptone yeast extract culture; ,$- \mathrm{pH}$ above 5.7 and within $0.3 \mathrm{pH}$ unit of the $\mathrm{pH}$ of a peptone yeast extract culture; + , positive reaction; $v$, variable among strains (40 to $60 \%$ of the strains acid [sugars] or were positive).

${ }^{b}$ Except where noted, all strains tested produced the reaction shown. The numbers in parenthesis indicate the percentages of strains that produced acid or gave a positive reaction.
}

to 5.1. Addition of $10 \%(\mathrm{vol} / \mathrm{vol})$ serum enhances growth and fermentation of some strains.

The major fermentation acids detected in cultures of the type strain grown in broth medium containing $1 \%$ peptone, $1 \%$ yeast extract, $1 \%$ glucose, vitamin K, and hemin (8) are (in milliequivalents per $100 \mathrm{ml}$ of culture): succinic, 4 ; acetic, 2 . Isobutyric acid $(0.1$ to $0.4 \mathrm{meq} / 100 \mathrm{ml})$ and isovaleric acid $(0.1$ to $0.4 \mathrm{meq} / 100 \mathrm{ml})$ also are detected. No hydrogen is detected in the headspace gas. Similar products are obtained with other strains. Neither lactate nor pyruvate is used; threonine is not converted to propionate.

Hemin and vitamin $\mathrm{K}$ are required for growth.

Of six strains tested, two are resistant to penicillin $\mathrm{G}(2 \mathrm{U} / \mathrm{ml})$, one is resistant to tetracycline $(6 \mu \mathrm{g} / \mathrm{ml})$, and two is resistant to both penicillin $\mathbf{G}$ and tetracycline. All six strains are susceptible to chloramphenicol $(12 \mu \mathrm{g} / \mathrm{ml})$ and clindamycin $(1.6 \mu \mathrm{g} / \mathrm{ml})$.
Other characteristics of the species are given in Table 5 .

Strains of this species have been isolated from various types of human clinical specimens.

The $\mathrm{G}+\mathrm{C}$ content of the DNA is 43 to 46 mol\%.

The type strain is ATCC $33547^{\mathrm{T}}$ (= VPI 9342 $=$ Lambe 532-70A).

In Bergey's Manual of Determinative Bacteriology, 8th ed. (10), B. melaninogenicus included the following three subspecies: $B$. melaninogenicus subsp. melaninogenicus, B. melaninogenicus subsp. intermedius, and $B$. melaninogenicus subsp. asaccharolyticus. B. melaninogenicus subsp. asaccharolyticus has been elevated to species rank (3), and we propose in this paper that $B$. melaninogenicus subsp. intermedius be elevated to species rank. Van Steenbergen (45) has reported that the LEV strain of " $B$. melaninogenicus subsp. levii" has 0 to $10 \%$ homology with the type strain of either Bacteroides asac- 
TABLE 6. Some differential characteristics for species formerly classified as $B$. melaninogenicus (Oliver and Wherry 1921) Roy and Kelly ${ }^{a}$

\begin{tabular}{|c|c|c|c|c|c|c|c|c|c|c|c|}
\hline \multirow[b]{2}{*}{ Species } & \multicolumn{6}{|c|}{ Acid produced from: } & \multirow{2}{*}{$\begin{array}{l}\text { In- } \\
\text { dole }\end{array}$} & \multirow{2}{*}{$\begin{array}{l}\mathrm{G}+\mathrm{C} \\
\text { content } \\
\text { (mol \%) }\end{array}$} & \multicolumn{2}{|c|}{ Products from $\mathrm{PYG}^{b}$} & \multirow[b]{2}{*}{$\begin{array}{l}\text { Other character- } \\
\text { istics }\end{array}$} \\
\hline & $\begin{array}{l}\text { Glu- } \\
\text { cose }\end{array}$ & $\begin{array}{l}\text { Lac- } \\
\text { tose }\end{array}$ & $\begin{array}{l}\text { Su- } \\
\text { crose }\end{array}$ & $\begin{array}{l}\text { Escu- } \\
\text { lin }\end{array}$ & $\begin{array}{l}\text { Cello- } \\
\text { biose }\end{array}$ & $\begin{array}{c}\text { Ri- } \\
\text { bose }\end{array}$ & & & Major & Other $^{c}$ & \\
\hline $\begin{array}{l}\text { B. melanino- } \\
\text { genicus }\end{array}$ & + & + & + & - & - & - & - & $40-43^{d}$ & $S, A$ & IB, IV, (F) & Lipase negative \\
\hline B. denticola & + & + & + & + & - & v & - & $49-51^{d}$ & $\mathbf{S}, \mathbf{A}$ & (IB), (IV), (L) & Lipase negative \\
\hline B. loescheii & + & - & + & - & + & - & + & $40-45^{d}$ & $\mathbf{S}, \mathbf{A}$ & (L), (F) & Lipase negative \\
\hline B. intermedius & + & - & + & - & - & - & + & $40-45^{e}$ & $\mathbf{S}, \mathbf{A}$ & (IB), (IV) & $\begin{array}{l}\text { Lipase usually } \\
\text { produced }\end{array}$ \\
\hline B. corporis & + & - & - & - & - & - & - & $43-46^{e}$ & S, A & (IB), (IV) & Lipase negative \\
\hline B. levii & + & + & - & - & - & - & - & $45-46^{f}$ & A, P, B & IV, IB, S & $\begin{array}{l}\text { Isolated from } \\
\text { cattle }\end{array}$ \\
\hline B. macacae & + & + & - & - & - & - & + & $43-45^{f}$ & $\mathrm{P}, \mathrm{S}$ & $\underset{\text { (PA) }}{\mathrm{IV}, \mathrm{A}, \mathrm{B}}$ & $\begin{array}{l}\text { Catalase posi- } \\
\text { tive }\end{array}$ \\
\hline $\begin{array}{l}\text { B. asaccharo- } \\
\text { lyticus }\end{array}$ & - & - & - & - & - & - & + & $52-54$ & B, A & $\begin{array}{l}P, I B, I V, \\
(L),(S)\end{array}$ & $\begin{array}{l}\text { Does not pro- } \\
\text { duce phenyl- } \\
\text { acetate }(14 \\
29,30)^{8}\end{array}$ \\
\hline B. gingivalis & - & - & - & - & - & - & + & $48-50^{f}$ & B & $\begin{array}{l}\mathrm{IB}, \mathrm{A}, \mathrm{P}, \mathrm{IV} \\
\quad \text { (S) }\end{array}$ & $\begin{array}{l}\text { Produces phen- } \\
\text { ylacetate (14, } \\
30) \text { and } \\
\text { sheep eryth- } \\
\text { rocyte agglu- } \\
\text { tinin (41) }\end{array}$ \\
\hline
\end{tabular}

$a+$, Positive reaction for 90 to $100 \%$ of the strains; - , negative reaction for 90 to $100 \%$ of the strains; $v, 40$ to $60 \%$ of the strains were positive.

${ }^{b}$ PYG, Broth containing $1 \%$ peptone, $1 \%$ yeast extract, $1 \%$ glucose, vitamin $\mathrm{K}$, and hemin (8); $\mathrm{A}$, acetic acid; B, butyric acid; F, formic acid; IB, isobutyric acid; IV, isovaleric acid; L, lactic acid; P, propionic acid; PA, phenylacetic acid; $S$, succinic acid. The products in parentheses may or may not be produced.

${ }^{c}$ Products produced in moderate or trace amounts.

${ }^{d}$ Values for $\mathrm{G}+\mathrm{C}$ content of DNA obtained from the data of Holdeman and Johnson (9a) and Van Steenbergen (45).

Values for $\mathrm{G}+\mathrm{C}$ content of DNA obtained from the present study and from the data of Van Steenbergen (45).

$f$ Values for G+C content of DNA obtained from the data of Van Steenbergen (45) and Coykendall et al. (1).

${ }^{8}$ The numbers in parentheses are reference numbers.

charolyticus or $B$. intermedius or with reference strains of Bacteroides gingivalis and B. melaninogenicus. The LEV strain is most like Bacteroides macacae phenotypically but does not produce indole or catalase, as do strains of $B$. macacae, and is serologically distinct (as determined by immunodiffusion) from $B$. macacae (42). Therefore, we propose the name Bacteroides levii sp. nov., with ATCC $29147^{\mathrm{T}}$ (= LEV strain = VPI 3300) as the type strain. The description of this species is given below.

Bacteroides levii. Bacteroides levii sp. nov. (lev'i.i. L. gen.n. levii of Lev, named for Meir Lev, the American-English microbiologist who first isolated this organism; "Bacteroides melaninogenicus subsp. levii" Holdeman, Cato, and Moore 1977 [32]).

Except where otherwise noted, this description is based on our study of the LEV strain (ATCC $29147^{\mathrm{T}}$ ) and two phenotypically similar strains (including strain JP-2 $[33,43]$ ) isolated from cattle.
In glucose broth cultures, cells are 0.6 to 1.2 by 2 to $7 \mu \mathrm{m}$ and occur in pairs and short chains (Fig. 4).

Surface colonies on anaerobic blood agar plates are minute, circular, entire, and low convex. After incubation for 2 to 3 days, colonies are buff to light brown; dark brown colonies develop after incubation for 5 to 7 days. No lipase or lecithinase activity is observed on egg yolk agar (8).

Glucose broth cultures are turbid with a smooth sediment and had a final $\mathrm{pH}$ of 5.5 .

In addition to the characteristics given in Table 6, gelatin, casein, milk, and meat are digested. There is no fermentation of adonitol, amygdalin, arabinose, dextrin, dulcitol, erythritol, fructose, glycerol, glycogen, inositol, inulin, maltose, mannitol, salicin, sorbitol, sorbose, starch, trehalose, or xylose. Nitrate is not reduced, catalase is not produced, and hippurate is not hydrolyzed. No growth occurred in peptoneyeast extract-glucose broth supplemented with 
TABLE 7. Proposed classification of some commonly used reference strains of pigmenting bacteroides previously classified as $B$. melaninogenicus subsp. intermedius and of the LEV strain

\begin{tabular}{|c|c|c|c|}
\hline \multirow{2}{*}{ Strain $^{a}$} & \multicolumn{2}{|c|}{ Identification or classification } & \multirow{2}{*}{ Reference(s) } \\
\hline & Present & Previous & \\
\hline 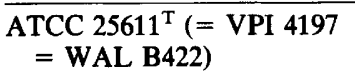 & B. intermedius & $\begin{array}{l}\text { B. melaninogenicus } \\
\text { subsp. intermedius }\end{array}$ & $3,5,12,27,45$ \\
\hline $\begin{array}{l}\text { VPI } 4200 \text { (= Finegold } \\
\text { B485) }\end{array}$ & B. intermedius & $\begin{array}{l}\text { B. melaninogenicus } \\
\text { subsp. intermedius }\end{array}$ & 3 \\
\hline $\begin{array}{l}\text { NCTC } 9336(=\text { VPI } 8944= \\
\text { Lambe } 729-74)\end{array}$ & $\begin{array}{l}B . \text { intermedius } \\
8944 \text { subgroup }\end{array}$ & B. melaninogenicus & $\begin{array}{c}3,6,12,35,38 \\
43,45-47\end{array}$ \\
\hline $\begin{array}{l}\text { ATCC } 25261(=\text { VPI } 4203 \\
=\text { WAL B515 = Lambe } \\
\text { 724-74) }\end{array}$ & $\begin{array}{l}\text { B. intermedius } \\
8944 \text { subgroup }\end{array}$ & $\begin{array}{l}\text { B. melaninogenicus } \\
\text { subsp. intermedius }\end{array}$ & $16,33,38,45$ \\
\hline $\begin{array}{l}\text { NCTC } 9338 \text { (= Lambe 206- } \\
\text { 74) }\end{array}$ & $\begin{array}{l}\text { B. intermedius VPI } \\
8944 \text { subgroup }\end{array}$ & $\begin{array}{l}\text { B. melaninogenicus } \\
\text { subsp. intermedius }\end{array}$ & $3,6,15,38,47$ \\
\hline $\begin{array}{l}\text { Williams T584 (= Lambe } \\
731-74=\text { VPI 9145) }\end{array}$ & $\begin{array}{l}\text { B. intermedius VPI } \\
8944 \text { subgroup }\end{array}$ & $\begin{array}{l}\text { B. melaninogenicus } \\
\text { subsp, intermedius }\end{array}$ & $16,35,38$ \\
\hline T588 (= Lambe 733-74) & $\begin{array}{l}\text { B. intermedius VPI } \\
8944 \text { subgroup }\end{array}$ & $\begin{array}{l}\text { B. intermedius subsp. } \\
\text { melaninogenicus }\end{array}$ & $36,43,45-47$ \\
\hline C11a-d2 (Carlsson) & $\begin{array}{l}\text { B. intermedius VPI } \\
8944 \text { subgroup }\end{array}$ & $\begin{array}{l}\text { B. melaninogenicus } \\
\text { subsp. intermedius }\end{array}$ & 33,38 \\
\hline LH-107 & $\begin{array}{l}\text { B. intermedius VPI } \\
8944 \text { subgroup }\end{array}$ & $\begin{array}{l}\text { B. melaninogenicus } \\
\text { subsp. intermedius }\end{array}$ & 38 \\
\hline JP1 & $\begin{array}{l}\text { B. intermedius VPI } \\
8944 \text { subgroup }\end{array}$ & $\begin{array}{l}\text { B. melaninogenicus } \\
\text { subsp. intermedius }\end{array}$ & 38 \\
\hline $\begin{array}{l}\text { ATCC } 33547^{\mathrm{T}}(=\text { VPI } 9342 \\
=\text { Lambe } 532-70 \mathrm{~A})\end{array}$ & B. corporis & $\begin{array}{l}\text { B. melaninogenicus } \\
\text { subsp. intermedius }\end{array}$ & $\frac{12,16,33,43}{45}$ \\
\hline $\begin{array}{l}\text { Lambe } 532-70 \mathrm{~A} \text { (= VPI } \\
\text { 9342) }\end{array}$ & B. corporis & $\begin{array}{l}\text { B. melaninogenicus } \\
\text { subsp. intermedius }\end{array}$ & 16,45 \\
\hline $\begin{array}{l}\text { ATCC } 29147^{\mathrm{T}}(=\mathrm{LEV} \\
\text { strain }=\text { VPI } 10450= \\
\text { VPI } 3300)^{b}\end{array}$ & B. levii & $\begin{array}{l}\text { B. melaninogenicus, } \\
\text { "B. melaninogeni- } \\
\text { cus subsp. levii" }\end{array}$ & $\begin{array}{l}8,33,43,45 \\
46\end{array}$ \\
\hline
\end{tabular}

a ATCC, American Type Culture Collection, Rockville, Md.; Carlsson, J. Carlsson, University of Umea, Umea, Sweden; Lambe, Dwight W. Lambe, Jr., East Tennessee State University, Johnson City; NCTC, National Collection of Type Cultures, Central Public Health Laboratory, London, England; VPI, Virginia Polytechnic Institute and State University Anaerobe Laboratory, Blacksburg; WAL, Wadsworth Veterans Administration Hospital Anaerobe Laboratory, Los Angeles, Calif. (usually received from S. M. Finegold or Vera Sutter); Williams, R. A. D. Williams, London Hospital Medical College, London, England.

$20 \%$ bile or $6.5 \% \mathrm{NaCl}$. The optimum temperature for growth is 35 to $37^{\circ} \mathrm{C}$; growth at 30 or $45^{\circ} \mathrm{C}$ is delayed and partially inhibited.

The major fermentation acids detected in cultures of the type strain grown in broth medium containing $1 \%$ peptone, $1 \%$ yeast extract, $1 \%$ glucose, vitamin $\mathrm{K}$, and hemin (8) are (in milliequivalents per $100 \mathrm{ml}$ of culture): acetic, 2; propionic, 1.5 to 2 ; butyric, 1 to 1.5 ; and isovaleric, 1 to 1.5 . Isobutyric acid $(0.5 \mathrm{meq} / 100 \mathrm{ml})$ and a small amount of succinic acid $(0.3 \mathrm{meq} / 100$ $\mathrm{ml}$ ) also are detected. Pyruvate is converted to acetate and propionate. Lactate is not utilized, and threonine was not converted to propionate.

Vitamin $\mathbf{K}$ and hemin are required for growth (17-19). Succinate stimulates growth and can replace the requirement for heme. Cytochrome $b$ is synthesized from heme and is not detected in the absence of heme (22). Glutamine stimulates growth and results in increased uptake of many amino acids and dipeptides (21). The cells possess superoxide dismutase activity (4).
Further information on the biochemical properties of $B$. levii has been described by Lev (18, 20) and Lev and Milford (23-26).

This species has been isolated from the bovine rumen, a cattle horn abscess, and a case of bovine summer mastitis.

The $\mathrm{G}+\mathrm{C}$ content of the DNA has been reported to be 45 to $46 \mathrm{~mol} \%$ by $T_{m}(45)$ and 48 mol\% by bouyant density (34).

The type strain is ATCC $29147^{\mathrm{T}}$ (= LEV strain).

Additional comments. Strains with similar phenotypic characteristics have been isolated from human clinical specimens. The genetic relatedness between the human and bovine isolates has not been investigated by DNA homology studies.

The major phenotypic characteristics by which $B$. intermedius, $B$. corporis, and $B$. levii differ from each other and from other species that previously have been considered " $B$. melaninogenicus" are given in Table 6. 


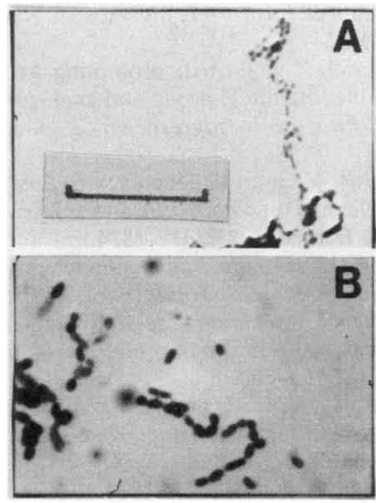

FIG. 2. Gram stains of 24-h broth cultures of $B$. intermedius VPI 4197 (= ATCC $25611^{\mathrm{T}}$ ) in peptoneyeast extract broth (A) and peptone-yeast extractglucose broth (B). Bar $=10 \mu \mathrm{m}$.

As we have observed and has been noted by other workers $(6,16,45)$, pigment formation is not an exceedingly reliable characteristic for differentiating between " $B$. melaninogenicus" and phenotypically similar organisms that may produce buff or creamy colonies upon continued incubation. Therefore, the ability to recognize the different species by characteristics other than pigment production is highly desirable. Except for production of pigmented colonies on blood agar, $\boldsymbol{B}$. intermedius and $\boldsymbol{B}$. corporis are most like $B$. disiens $(9)$, which also does not ferment lactose and does not grow well, if at all, in peptone-yeast extract-glucose medium supplemented with $20 \%$ bile $(2 \mathrm{~g}$ of oxgall per 100 $\mathrm{ml})$. Fermentation of sucrose and production of indole by $B$. intermedius but not by $B$. disiens differentiate these species. There is no one sub. strate reaction that reliably differentiates between $B$. corporis and B. disiens. Fortunately,

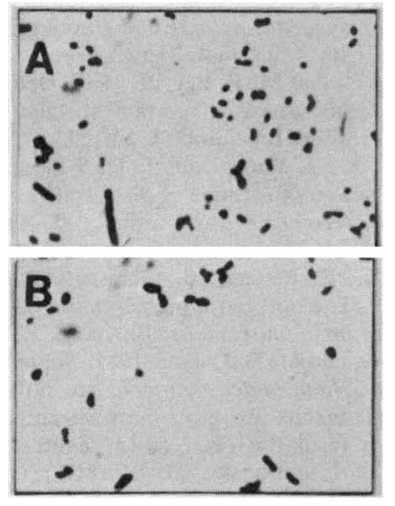

FIG. 3. Gram stains of 24-h broth cultures of $B$. corporis VPI $9342\left(=\right.$ ATCC $\left.33547^{\mathrm{T}}\right)$ in peptone yeast extract broth (A) and peptone-yeast extract-glucose broth (B). See Fig. 2 for magnification.

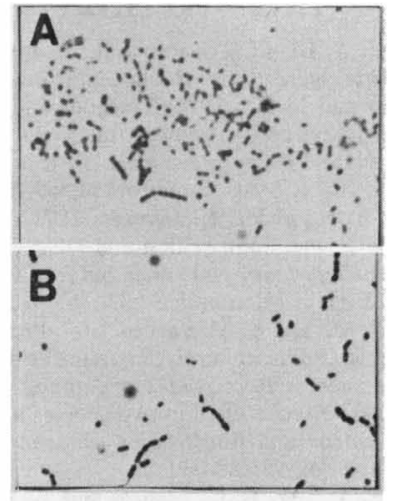

FIG. 4. Gram stains of 24-h broth cultures of $B$. levii VPI 3300 (= LEV strain) in peptone-yeast extract broth (A) and peptone-yeast extract-glucose broth (B). See Fig. 2 for magnification.

all strains of $B$. corporis that we have isolated have pigmented reliably on blood agar within 4 to 7 days, and distinct pigmentation has not been observed with strains of $B$. disiens. The patterns of soluble proteins in polyacrylamide gel electrophoresis gels also clearly differentiate these two species (data not shown). All strains of $B$. disiens digest milk and meat, and some strains of $B$. corporis may not digest one or the other of these complex proteins. Tests for digestion are not considered negative until cultures have been incubated for 3 weeks. Freshly isolated strains of $\boldsymbol{B}$. disiens do not digest milk and meat as rapidly as laboratory stock cultures do. Fermentation of glycogen, fermentation of maltose, and fermentation of starch by $B$. bivius and $B$. disiens are helpful in differentiating between these species and $B$. levii.

\section{ACKNOWLEDGMENTS}

We gratefully acknowledge the persons who sent strains used in these studies and the help of K. Palcanis, R. R. Ranney, and J. A. Burmeister, School of Dentistry, Virginia Commonwealth University, who selected the subjects and sites to be sampled for the periodontal samples and who obtained the samples from which we isolated strains. We are especially grateful to T. O. MacAdoo, Department of Foreign Languages and Literature, Virginia Polytechnic Institute and State University, for suggesting appropriate specific epithets that are distinct from those in other genera and for etymologies of specific epithets. We appreciate the help of E. P. Cato and D. E. Hash in electrophoretic analyses, of W. E. C. Moore for assistance in isolation and identification of the periodontal strains, and of E. P. Cato and W. E. C. Moore for critical review of the manuscript. We gratefully acknowledge the technical assistance of Ann C. Ridpath, Luba S. Fabrycky, Debbie B. Sinsabaugh, and Pamela J. Churn.

This work was supported in part by Public Health Service grants DE-05128, DE-05139 (Virginia Commonwealth University Clinical Research Center for Periodontal Diseases), and DE-05054 from the National Institute of Dental Research, by Public Health Service grant AI-15244 from the National Institute of Allergy and Infectious Diseases, and by project 2022820 from the Commonwealth of Virginia. 


\section{LITERATURE CITED}

1. Coykendall, A. L., F. S. Kaczmarek, and J. Slots. 1980. Genetic heterogeneity in Bacteroides asaccharolyticus (Holdeman and Moore 1970) Finegold and Barnes 1977 (Approved Lists, 1980) and proposal of Bacteroids gingivalis sp. nov. and Bacteroides macacae (Slots and Genco) comb. nov. Int. J. Syst. Bacteriol. 30:559-564.

2. Cummins, C. S., and J. L. Johnson. 1971. Taxonomy of the clostridia: wall composition and DNA homologies in Clostridium butyricum and other butyric acid-producing clostridia. J. Gen. Microbiol. 67:33-46.

3. Finegold, S. M., and E. M. Barnes. 1977. Proposal that the saccharolytic and asaccharolytic strains at present classified in the species Bacteroides melaninogenicus (Oliver and Wherry) be reclassified in two species as Bacteroides melaninogenicus and Bacteroides asaccharolyticus. Int. J. Syst. Bacteriol. 27:388-391.

4. Gregory, E. M., W. E. C. Moore, and L. V. Holdeman. 1978. Superoxide dismutase in anaerobes: survey. Appl. Environ. Microbiol. 35:988-991.

5. Hofstad, T. 1974. The distribution of heptose and 2-keto-3deoxy-octonate in Bacteroidaceae. J. Gen. Microbiol. 85:314-320.

6. Holbrook, W. P., B. I. Duerden, and A. G. Deacon. 1977. The classification of Bacteroides melaninogenicus and related species. J. Appl. Bacteriol. 42:259-273.

7. Holbrook, W. P., and C. McMillan. 1977. The hydrolysis of dextran by gram negative non-sporing anaerobic bacilli. J. Appl. Bacteriol. 43:369-374.

8. Holdeman, L. V., E. P. Cato, and W. E. C. Moore (ed.). 1977. Anaerobe laboratory manual. Anaerobe Laboratory, Virginia Polytechnic Institute and State University, Blacksburg.

9. Holdeman, L. V., and J. L. Johnson. 1977. Bacteroides disiens sp. nov. and Bacteroides bivius sp. nov. from human clinical infections. Int. J. Syst. Bacteriol. 27:337345 .

9a.Holdeman, L. V., and J. L. Johnson. 1982. Description of Bacteroides loescheii sp. nov. and emendation of the descriptions of Bacteroides melaninogenicus (Oliver and Wherry) Roy and Kelly 1939 and Bacteroides denticola Shah and Collins 1981. Int. J. Syst. Bacteriol. 32:399-409.

10. Holdernan, L. V., and W. E. C. Moore. 1970. Bacteroides, p. 34-44. In E. P. Cato, C. S. Cummins, L. V. Holdeman, J. L. Johnson, W. E. C. Moore, R. M. Smibert, and L. DS. Smith (ed.), Outline of clinical methods in anaerobic bacteriology, 2nd rev. Anaerobe Laboratory, Virginia Polytechnic Institute and State University, Blacksburg.

11. Holdeman, L. V., and W. E. C. Moore. 1974. Genus I. Bacteroides Castellani and Chalmers 1919, 959, p. 385404. In R. E. Buchanan and N. E. Gibbons (ed.), Bergey's manual of determinative bacteriology, 8 th ed. The Williams \& Wilkins Co., Baltimore.

12. Johnson, J. L. 1980. Classification of anaerobic bacteria, p. 19-29. In Proceedings of International Symposium on Anaerobes, Tokyo, Japan, June 22, 1980. Nippon MerckBanyu Co., Ltd., Tokyo.

13. Johnson, J. L. 1981. Genetic characterization, p. 450-472. In P. Gerhardt (ed.), Manual of methods for general microbiology. American Society for Microbiology, Washington, D.C.

14. Kaczmarek, F. S., and A. L. Coykendall. 1980. Production of phenylacetic acid by strains of Bacteroides asaccharolyticus and Bacteroides gingivalis (sp. nov.). J. Clin. Microbiol. 12:288-290.

15. Lambe, D. W., Jr. 1974. Determination of Bacteroides melaninogenicus serogroups by fluorescent antibody staining. Appl. Microbiol. 28:561-567.

16. Lambe, D. W., Jr., and R. C. Jerris. 1976. Description of a polyvalent conjugate and a new serogroup of Bacteroides melaninogenicus by fluorescent antibody staining. J. Clin. Microbiol. 3:506-512.

17. Lev, M. 1958. Apparent requirement for vitamin $\mathrm{K}$ of rumen strains of Fusiformis nigrescens. Nature (London) 181:203-204.

18. Lev, M. 1959. The growth promoting activity of compounds of the vitamin $\mathrm{K}$ group and analogues for a rumen strain of Fusiformis nigrescens. J. Gen. Microbiol. 20:697-703.

19. Lev, M. 1968. Vitamin K deficiency in Fusiformis nigrescens. I. Influence on whole cells and cell envelope characteristics. J. Bacteriol. 95:2317-2324.

20. Lev, M. 1977. Casamino Acids enhance growth of Bacteroides melaninogenicus. J. Bacteriol. 129:562-563.

21. Lev, M. 1980 . Glutamine-stimulated amino acid and peptide incorporation in Bacteroides melaninogenicus. J. Bacteriol. 143:753-760.

22. Lev, M., K. C. Keudell, and A. F. Milford. 1971. Succinate as a growth factor for Bacteroides melaninogenicus. J. Bacteriol. 108:175-178.

23. Lev, M., and A. F. Milford. 1972. Effect of vitamin K depletion and restoration on sphingolipid metabolism in Bacteroides melaninogenicus. J. Lipid Res. 13:364-370.

24. Lev, M., and A. F. Milford. 1973. The 3-keto dihydrosphingosine synthetase of Bacteroides melaninogenicus: induction by vitamin K. Arch. Biochem. Biophys. 157:500-508.

25. Lev, M., and A. F. Milford. 1977. Energy-dependent incorporation of sphingolipid precursors and fatty acids in Bacteroides melaninogenicus. J. Bacteriol. 130:445-454.

26. Lev, M., and A. F. Milford. 1978. Role of nucleosides, 5phosphoribosyl-1-pyrophosphate and ribose-1-phosphate in the biosynthesis of phosphospingolipids in Bacteroides melaninogenicus. Arch. Biochem. Biophys. 185:82-87.

27. Listgarten, M. A., and C.-H. Lai. 1979. Comparative ultrastructure of Bacteroides melaninogenicus subspecies. J. Periodontal Res. 14:332-340.

28. Marmur, J. 1961. A procedure for the isolation of deoxyribonucleic acid from microorganisms. J. Mol. Biol. 3:208218.

29. Mayrand, D. 1979. Identification of clinical isolates of selected species of Bacteroides: production of phenylacetic acid. Can. J. Microbiol. 25:927-928.

30. Mayrand, D., B. C. McBride, T. Edwards, and S. Jensen. 1980. Characterization of Bacteroides asaccharolyticus and $B$. melaninogenicus oral isolates. Can. J. Microbiol. 26:1178-1183.

31. Miles, D. O., J. K. Dyer, and J. C. Wong. 1976. Influence of amino acids on the growth of Bacteroides melaninogenicus. J. Bacteriol. 127:899-903.

32. Moore, W. E. C., D. E. Hash, L. V. Holdeman, and E. P. Cato. 1980. Polyacrylamide slab gel electrophoresis of soluble proteins for studies of bacterial floras. Appl. Environ. Microbiol. 39:900-907.

33. Mouton, C., P. Hammond, J. Slots, and R. Genco. 1980. Evaluation of Fluorotec-M for detection of oral strains of Bacteroides asaccharolyticus and Bacteroides melaninogenicus. J. Clin. Microbiol. 11:682-686.

34. Reddy, C. A., and M. P. Bryant. 1977. Deoxyribonucleic acid base composition of certain species of the genus Bacteroides. Can. J. Microbiol. 23:1252-1256.

35. Salyers, A. A., J. Wong, and T. D. Wilkins. 1977. Betalactamase activity in strains of Bacteroides melaninogenicus and Bacteroides oralis. Antimicrob. Agents Chemother. 11:142-146.

36. Shah, H. N., R. Bonnett, B. Mateen, and R. A. D. Williams. 1979. The porphyrin pigmentation of subspecies of Bacteroides melaninogenicus. Biochem. J. 180:45-50.

37. Shah, H. N., and M. D. Collins. 1981. Bacteroides buccalis sp. nov., Bacteroides denticola sp. nov., and Bacteroides pentosaceus sp. nov., new species of the genus Bacteroides from the oral cavity. Zentralbl. Bakteriol. Parasitenkd. Infektionskr. Hyg. Abt. 1 Orig. Reihe C 2:235-241.

38. Shah, H. N., R. A. D. Williams, G. H. Bowden, and J. M. Hardie. 1976. Comparison of the biochemical properties of Bacteroides melaninogenicus from human dental plaque and other sites. J. Appl. Microbiol. 41:473-492. 
39. Skerman, V. B. D., V. McGowan, and P. H. A. Sneath (ed.). 1980. Approved lists of bacterial names. Int. J. Syst. Bacteriol. 30:225-420.

40. Skerman, V. B. D., V. McGowan, and P. H. A. Sneath (ed.). 1982. Validation of the publication of new names and new combinations previously effectively published outside the IJSB, list no. 8. Int. J. Syst. Bacteriol. 32:266268.

41. Slots, J., and R. J. Genco. 1979. Direct hemagglutination technique for differentiating Bacteroides asaccharolyticus oral strains from nonoral strains. J. Clin. Microbiol. 10:371-373.

42. Slots, J., and R. J. Genco. 1980. Bacteroides melaninogenicus subsp. macacae, a new subspecies from monkey periodontopathic microflora. Int. J. Syst. Bacteriol. 30:82-85.

43. Swindlehurst, C. A., H. N. Shah, C. W. Parr, and R. A. D. Williams. 1977. Sodium dodecyl sulphate-polyacrylamide gel electrophoresis of polypeptides from $\mathrm{BaC}$ - teroids melaninogenicus. J. Appl. Bacteriol. 43:319-324.

44. Tereba, A., and B. J. McCarthy. 1973. Hybridization of ${ }^{125}$ I-labeled ribonucleic acid. Biochemistry 12:4675-4679.

45. Van Steenbergen, T. J. M. 1981. Classification and virulence of black-pigmented Bacteroides strains. Vrije University, Amsterdam.

46. Van Steenbergen, T. J. M., J. J. de Soet, and J. de Graaff. 1979. DNA base composition of various strains of Bacteroides melaninogenicus. FEMS Microbiol. Lett. 5:127130.

47. Williams, R. A. D., G. H. Bowden, J. M. Hardie, and H. Shah. 1975. Biochemical properties of Bacteroides melaninogenicus subspecies. Int. J. Syst. Bacteriol. 25:298300 .

48. Wong, J. C., J. K. Dyer, and J. L. Tribble. 1977. Fermentation of $\mathrm{L}$-aspartate by a saccharolytic strain of Bacteroides melaninogenicus. Appl. Environ. Microbiol. 33:69-73. 